\title{
$\beta$-Adrenergic Receptors and cAMP Response Increase during Explant Culture of Human Fetal Lung: Partial Inhibition by Dexamethasone
}

\author{
DEBORAH J. DAVIS,' MARK M. JACOBS, PHILIP L. BALLARD, LINDA K. GONZALES, AND \\ JAMES M. ROBERTS \\ Cardiovascular Research Institute [P.L.B., J.M.R.], Departments of Pediatrics [D.J.D., P.L.B., L.K.G.] and \\ Obstetrics, Gynecology and Reproductive Sciences [M.J.J., J.M.R.], University of California, \\ San Francisco, California 94143
}

\begin{abstract}
We studied $\beta$-adrenergic receptors and responses in human fetal lung (15-25 wk gestation) maintained in explant culture with and without added dexamethasone. To determine $\beta$-adrenergic receptor concentration, we performed radioligand binding assays with $\left[{ }^{125} \mathrm{I}\right]-$ iodocyanopindolol. We also examined the ability of isoproterenol to stimulate cAMP generation as a measure of response to $\beta$-adrenergic receptor occupancy. In control cultures, $\beta$-receptor concentration increased significantly from $\mathrm{d} 0$ to 3 of culture and thereafter remained stable. The $k_{d}(\sim 24 \mathrm{pM})$ of $\left[{ }^{125} \mathrm{I}\right]$-iodocyanopindolol did not change with time in culture. The ability of isoproterenol to stimulate cAMP generation over basal levels increased in controls throughout the $5 \mathbf{d}$ in explant culture. Addition of dexamethasone $(10 \mathrm{nM})$ to the culture medium partially blocked the increase in $\beta$-receptor concentration and decreased both cAMP content and generation (basal and stimulated) in a dose-dependent manner (median effective concentration $\sim 1 \mathrm{nM}$ ). In these same explants, dexamethasone increased the activity of fatty acid synthetase, an enzyme important in surfactant synthesis, more than 2fold. Our results indicate that $\beta$-adrenergic receptors and isoproterenol stimulation of cAMP generation increase spontaneously in human fetal lung grown in explant culture. Dexamethasone, which accelerates other aspects of human lung development in vitro, decreases $\beta$-adrenergic receptor concentration and inhibits $\beta$-adrenergic responses. (Pediatr Res 28: 190-195, 1990)
\end{abstract}

\section{Abbreviations}

ICYP, $\left[{ }^{125} \mathrm{I}\right]$-iodocyanopindolol

There is increasing clinical and experimental evidence that $\beta$ adrenergic responses play a key role in the adaptation of the fetal lung to extrauterine life (1). In vivo and in vitro, $\beta$-adrenergic agonists and cAMP analogues stimulate surfactant release and the synthesis of surfactant apoprotein and lipid. $\beta$-adrenergic receptors have been identified in human fetal lung during early gestation $(2,3)$ and the receptor concentration has been shown to increase between 15 and 23 wk gestation (3). In addition, lung $\beta$-adrenergic receptors are functionally linked to adenylate cy-

Received June 20, 1989; accepted April 23, 1990.

Correspondence: Dr. James M. Roberts, HSE 1462, UCSF, San Francisco, CA 94143.

Supported by NIH Grants HL30541, HL24056 and HL27356.

${ }^{1}$ Current address: Division of Neonatology, Children's Hospital of Eastern Ontario, Ottawa, Ontario K1H8L1. clase, as evidenced by the ability of isoproterenol to stimulate cAMP generation in human fetal lung as early as $20 \mathrm{wk}$ gestation (3).

Although the effects of explant culture and glucocorticoids on the $\beta$-adrenergic response cascade in human fetal lung have not been previously studied, several groups have demonstrated enhancement of morphologic maturation and increased surfactant synthesis in fetal lung of different species in vivo and in explant culture after glucocorticoid treatment (4). Maternal dexamethasone treatment increases the concentration of pulmonary $\beta$ adrenergic receptors in fetal rabbit $(5,6)$. In explant cultures of fetal rabbit (7-9) and rat (10) lung and in a cell line derived from adult human lung (11), glucocorticoids increase the concentration of $\beta$-adrenergic receptors. Additionally, maternal glucocorticoid treatment increased high affinity agonist $\beta$-receptor complexes in fetal rabbit lung (7), a functional alteration found previously in some adult tissues (12). In this study, we measured the concentration of $\beta$-adrenergic receptors and stimulation of cAMP generation in human fetal lung in explant culture. The effect of dexamethasone on the $\beta$-adrenergic response cascade in particulate fractions of human fetal lung explants was also determined. We found that $\beta$-adrenergic receptor concentration and $\beta$-adrenergic agonist-stimulated cAMP generation increase spontaneously but asynchronously in explant culture and, surprisingly, both of these responses are partially inhibited by dexamethasone.

\section{MATERIALS AND METHODS}

Explant culture. The human fetal lung explant culture system previously described (13) was used in these studies. Human fetal lung tissue was obtained from abortuses after elective terminations of pregnancy by dilatation and evacuation in the second trimester under a protocol approved by the UCSF Committee on Human Experimentation. Lungs were chopped into $1 \mathrm{~mm}$ cubes and cultured in $60 \mathrm{~mm}$ plastic dishes at a density of 50 $100 \mathrm{mg}$ tissue (wet wt) per dish and incubated in Waymouth's MB752/1 culture medium on a rocking platform at $37^{\circ} \mathrm{C}$ in a humidified atmosphere of $95 \%$ air $/ 5 \% \mathrm{CO}_{2}$ for up to $5 \mathrm{~d}$. One or more dishes from a single fetus maintained similarly are termed a set. The day of preparation was designated $\mathrm{d} 0$. Explants in most cases were maintained without dexamethasone overnight (approximately $16 \mathrm{~h}$ ), then treated explants had dexamethasone added at the time of the culture medium change the following day (d 1); control explants had culture medium with an equivalent volume of $70 \%$ ethanol (the diluent for the dexamethasone) added (final ethanol concentration $0.03 \%$ ). Fresh medium was added on alternate days. Lung tissue for preculture (d 0 ) determinations of receptor concentration or cAMP generation was collected immediately after chopping. The explants of lung tissue 
were otherwise collected at specified times. Samples for determination of receptor concentration were frozen and stored at $-70^{\circ} \mathrm{C}$ until membrane preparation. We have previously shown that under these conditions $\beta$-adrenergic receptor concentration was not different from that in fresh specimens (3). Samples for determination of cAMP generation were processed immediately after harvesting.

Reagents. $\left[2-{ }^{14} \mathrm{C}\right]$-malonyl $\mathrm{CoA}(41.1 \mathrm{mCi} / \mathrm{mmol})$, ICYP $(2200 \mathrm{Ci} / \mathrm{mmol})$, and $\left[{ }^{3} \mathrm{H}\right]$-cAMP $(32 \mathrm{Ci} / \mathrm{mmol})$ were purchased from New England Nuclear Corporation (Boston, MA). 1-Isoproterenol bitartrate, $3^{\prime} 5^{\prime}$-cAMP-dependent protein kinase, 3-isobutyl-1-methylxanthine, and other chemicals were purchased from Sigma Chemical Company (St. Louis, MO). Waymouth's MB752/1 culture medium was obtained from the Cell Culture Facility, UCSF, and was supplemented with penicillin (100 U/ $\mathrm{mL})$, streptomycin $(100 \mu \mathrm{g} / \mathrm{mL})$, and fungizone $(2.5 \mu \mathrm{g} / \mathrm{mL})$.

Membrane preparation. Partially purified membrane particulates were prepared by differential centrifugation as previously described (3). Protein concentration was determined using the Bradford method (14) with BSA as the standard. The partially purified crude membrane particulates were frozen in liquid nitrogen and stored at $-70^{\circ} \mathrm{C}$ until assayed.

Binding studies. To determine the $\beta$-adrenergic receptor concentration, saturation isotherms with concentrations of ICYP from 0.1 to $10 \mathrm{k}_{\mathrm{d}}(4-400 \mathrm{pM})$ were performed with membrane particulates from 17 explant cultures (12 controls and five dexamethasone-treated) and analyzed as we have previously described (3). Because these preliminary experiments indicated no change in affinity with the different treatments $(27 \pm 3 \mathrm{nM}$ control, $22 \pm 2 \mathrm{nM}$ dexamethasone-treated, $p>0.5, t$ test), we performed "one-point assays." In these assays, triplicate samples of each membrane particulate ( $30 \mu \mathrm{g}$ protein) were incubated at $30^{\circ} \mathrm{C}$ for $90 \mathrm{~min}$ in $0.25 \mathrm{~mL}$ containing $50 \mathrm{mM}$ Tris, $4 \mathrm{mM}$ magnesium chloride buffer ( $\mathrm{pH} 7.4$ ), $1 \mathrm{mM}$ ascorbic acid, 160 $\mathrm{pM}\left(\sim 5 \mathrm{k}_{\mathrm{d}}\right) \mathrm{ICYP}$, and $100 \mu \mathrm{M} \mathrm{HCl}$ for total binding or $100 \mu \mathrm{M}$ isoproterenol in $100 \mu \mathrm{M} \mathrm{HCl}$ to determine nonspecific binding. Filtration and washing were as described for standard saturation isotherms (3). There was no significant difference between the receptor concentrations determined by the saturation isotherm and the one-point method (data not shown). Therefore, to conserve tissue, the one-point method was used in most experiments.

cAMP generation. cAMP content was determined by incubating duplicate samples of 25 to $30 \mathrm{mg}$ of freshly harvested tissue from explant culture in $0.25 \mathrm{~mL} 5 \mathrm{mM}$ Tris and $0.9 \% \mathrm{NaCl}, 1$ $\mathrm{mM}$ 3-isobutyl-1-methylxanthine (a phosphodiesterase inhibitor), $0.1 \mathrm{mM}$ ascorbic acid, and $100 \mu \mathrm{M} \mathrm{HCl}$ for $10 \mathrm{~min}$ at $4^{\circ} \mathrm{C}$. Basal cAMP generation was determined by incubating duplicate samples of tissue in an identical buffer solution for $10 \mathrm{~min}$ at $37^{\circ} \mathrm{C}$. Stimulation of cAMP generation was performed with 1 $\mu \mathrm{M}$ isoproterenol or $100 \mu \mathrm{M}$ forskolin in $1 \%$ DMSO. Preliminary studies indicated no stimulatory effect of $1 \%$ DMSO. For all determinations, the reaction was stopped with an equal volume of $10 \%$ trichloroacetic acid. After homogenization and centrifugation, three consecutive 5:1 ether extractions were performed to remove trichloroacetic acid. Remaining ether was evaporated in a $70^{\circ} \mathrm{C}$ water bath for $20 \mathrm{~min}$. cAMP concentration was assessed either by a modification of the assay of Gilman (15), as previously described (3), or by a modification of the RIA described by Brooker et al. (16).

Fatty acid synthetase activity. The activity of fatty acid synthetase (EC 2.3.1.85) was determined by the incorporation of radioactive malonyl $\mathrm{CoA}$ by a modification (17) of the method of Roncari (18). Incubation time was $15 \mathrm{~min}$. Enzyme activity is expressed as nmol malate incorporated per $\mathrm{mg}$ protein per min. The assay was linear between 10 and $150 \mathrm{mg}$ protein per $\mathrm{mL}$ reaction mixture for $20 \mathrm{~min}$ and was optimized for concentrations of substrates and cofactor, which were prepared fresh.

Calculations and data analysis. Receptor concentration for the saturation analysis was determined by a computer-assisted analysis (19) of bound ICYP as a function of free ICYP; the data were then arrayed as described by Scatchard (20). Receptor concentration for the one-point analysis was calculated by subtracting nonspecific binding from total binding. Data for CAMP generation were derived from a linear regression using standard curves obtained from known amounts of nonradioactive cAMP added to the buffer. Previous studies indicated identical cAMP data derived from standard curves obtained with either nonradioactive cAMP added to buffer or to tissue extracts (3). Statistical analysis was by one- or two-factor analysis of variance, or where indicated, by linear regression analysis. Data are presented throughout as the mean plus or minus SEM.

\section{RESULTS}

The concentration of $\beta$-adrenergic receptors in 16-24 wk human fetal lung explants increased significantly during explant culture in the absence of added dexamethasone (Fig. 1). Receptor concentration increased significantly between $\mathrm{d} 0$ and 1 and between $\mathrm{d} 1$ and 3 , but did not change thereafter. The maximum receptor concentration after culture was $185 \pm 15 \mathrm{fmol} / \mathrm{mg}$ membrane protein. The $\mathrm{k}_{\mathrm{d}}$ for ICYP $(\sim 24 \mathrm{pM})$, determined from computer analysis of saturation isotherms, was the same in those membrane particulates prepared from explants either with or without dexamethasone exposure and did not change with time in culture (data not shown, $n=18$ ). cAMP content and basal cAMP generation in human fetal lung explants (15.2-25 wk) did not change with time in culture except for $\mathrm{d} 1$ when both values were significantly higher than at d 0 or 5 (Fig. $2 A$ ). By contrast, the absolute value of isoproterenol stimulation of CAMP increased significantly with time in culture. When cAMP generation was expressed as isoproterenol-stimulated generation minus basal generation, there was an increase in net cAMP generation with time (Fig. $2 B$ ). Similarly, when isoproterenol-stimulated cAMP generation was expressed as multiples of basal generation, there was a linear increase with time in culture at each day examined $\left(r^{2}=0.82\right.$, Fig. $\left.2 C\right)$.

Addition of dexamethasone $(10 \mathrm{nM})$ to the culture medium decreased the concentration of $\beta$-adrenergic receptors compared with that of controls (Fig. 3); this difference reached statistical significance after $4 \mathrm{~d}$ in culture ( $72 \mathrm{~h}$ exposure).

Initial experiments examined the effects of $10 \mathrm{nM}$ dexamethasone on cAMP generation in minces. This concentration of dexamethasone maximally stimulates both choline incorporation into phosphatidylcholine in fetal rabbit lung explants (21) and

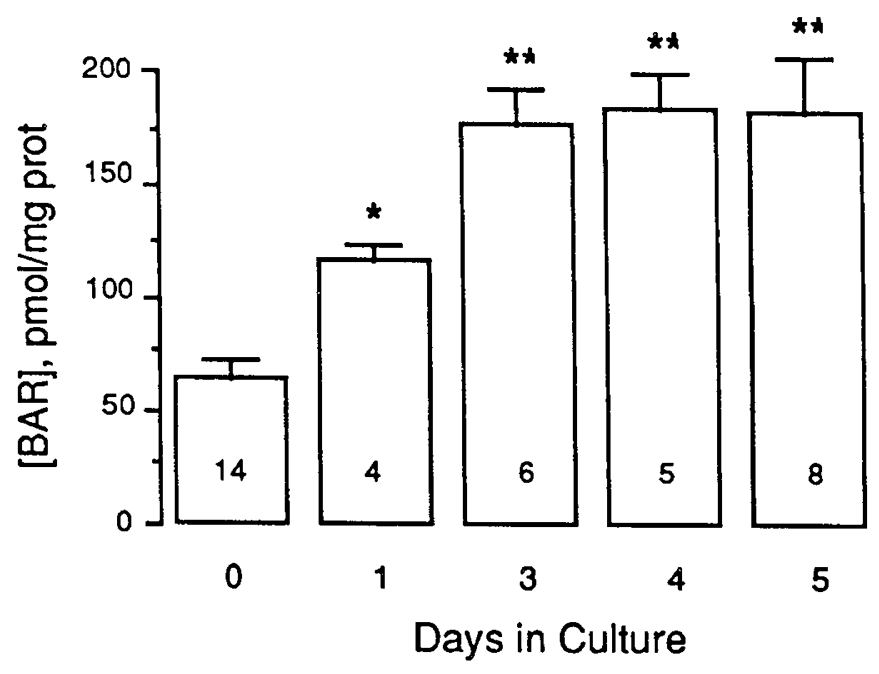

Fig. 1. $\beta$-adrenergic receptor concentration as a function of days in explant culture. Explants were harvested at specified times and partially purified membrane particulates were prepared. $*$ and $* *$ indicate significant differences by analysis of variance from d 0 and 1 , respectively ( $p$ $<0.05$ ). Data are the mean and SEM of triplicate determinations ( $n$ is indicated inside bar). 


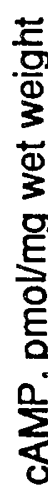

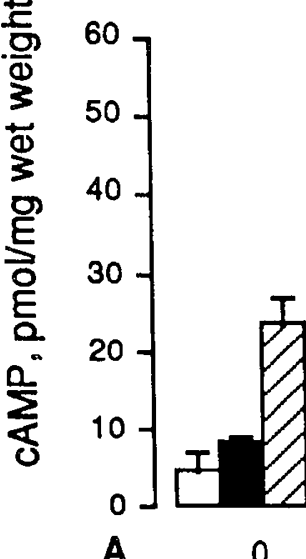

A

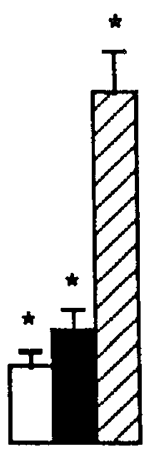

1

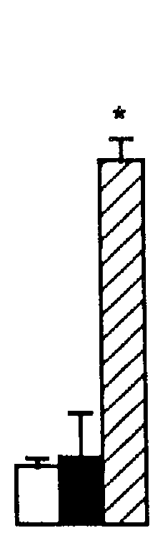

3

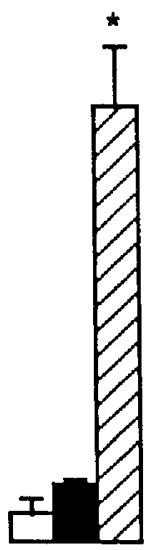

5

Days in Culture

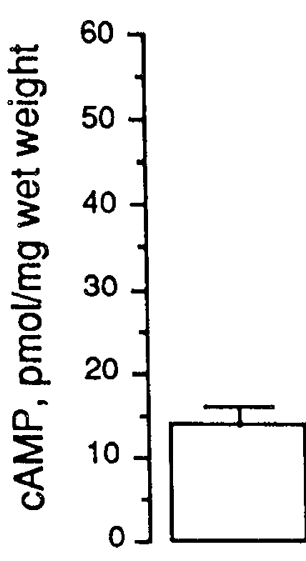

B

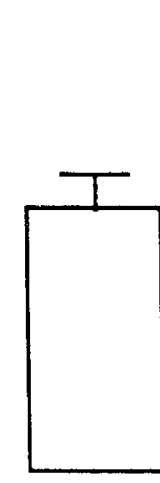

1

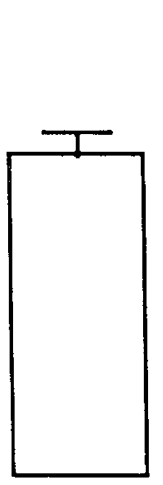

3

Days in Culture

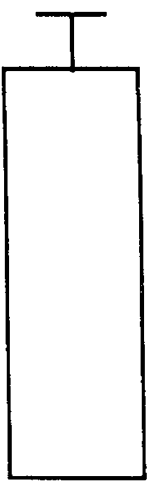

5

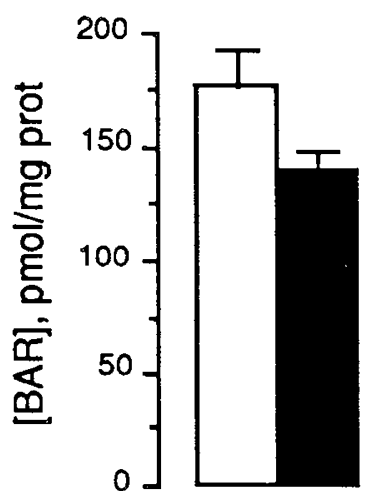

3

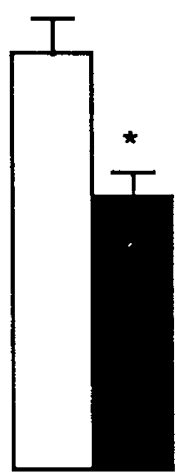

4

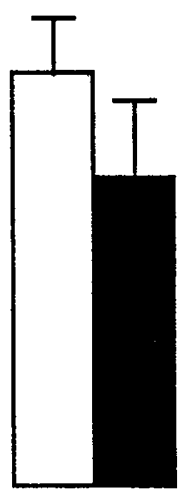

5

\section{Days in Culture}

Fig. 3. $\beta$-adrenergic receptor concentration after treatment with 10 $\mathrm{nM}$ dexamethasone (Dex). Two-way analysis of variance indicated a significant reduction after treatment $\left({ }^{*} p<0.05\right)$. Data are the mean and SEM of triplicate determinations of six sets of explants at d 3 control, three at $\mathrm{d} 3$ Dex, five at $\mathrm{d} 4$ control, five at $\mathrm{d} 4 \mathrm{Dex}$, eight at $\mathrm{d} 5$ control, and four at 5 Dex. Open bar, control; solid bar, Dex.

surfactant synthesis in human fetal lung explants (13). In our studies, $10 \mathrm{nM}$ dexamethasone significantly reduced cAMP generation in response to isoproterenol after $5 \mathrm{~d}$ (Fig. $4 B$ ) but not after $3 \mathrm{~d}$ in culture (Fig. $4 A$ ). Isoproterenol response was less at d 5 whether expressed as total cAMP generation or as net isoproterenol stimulation (minus basal stimulation, data not shown), but not if expressed as a multiples of basal stimulation (data not shown). No difference in basal cAMP generation was apparent at $3 \mathrm{~d}$ of dexamethasone exposure; mean values for basal cAMP generation were less with $5 \mathrm{~d}$ of dexamethasone exposure, although this did not achieve statistical significance.

Because the values obtained for basal cAMP generation were at the lower limits of sensitivity of our protein binding assay, further studies were performed using a sensitive RIA (16). In these studies, the dose response of dexamethasone to alter cAMP generation was determined. Five $\mathrm{d}$ of dexamethasone exposure decreased cAMP content (data not shown), and basal- (Fig. $5 A$ ), isoproterenol- (Fig. 5B), and forskolin- (Fig. 5C) stimulated cAMP generation in a dose-dependent manner. The concentration of dexamethasone resulting in the half-maximal inhibition of all the responses was approximately $1 \mathrm{nM}$. Although dexamethasone decreased both total and net isoproterenol stimulation, fold stimulation was unchanged (about 14-fold). There was no concentration of dexamethasone from $0.1 \mathrm{nM}$ to $100 \mathrm{nM}$ at which cAMP generation was augmented.

To ascertain that our experimental conditions did not produce generalized inhibition, fatty acid synthetase activity was measured in four sets of human fetal lung explants cultured for $5 \mathrm{~d}$ either with or without $10 \mathrm{nM}$ dexamethasone. Although these explants had reduced $\beta$-receptor concentration, fatty acid synthetase activity was 2.5 -fold greater after culture in the presence of dexamethasone (Fig. 6).

\section{DISCUSSION}

In this study, we have shown that the concentration of $\beta$ adrenergic receptors in human fetal lung increases spontaneously

duplicate determinations from 14 sets of explants at $\mathrm{d} 0$, six at $\mathrm{d} 1$, seven at d 3, and eight at d 5. B, cAMP generation expressed as isoproterenolstimulated minus basal-stimulated. Presented are the mean and SEM of the same data as in $2 A$. Values are greater at all days than at $\mathrm{d} 0$, and $\mathrm{d}$ 5 values are also greater than on $\mathrm{d} 1(p<0.05$, analysis of variance). $C$, Isoproterenol-stimulated cAMP generation expressed as a multiple of basal cAMP generation in the same experiment. Presented are the mean and SEM of the same data as in $2 A$. 


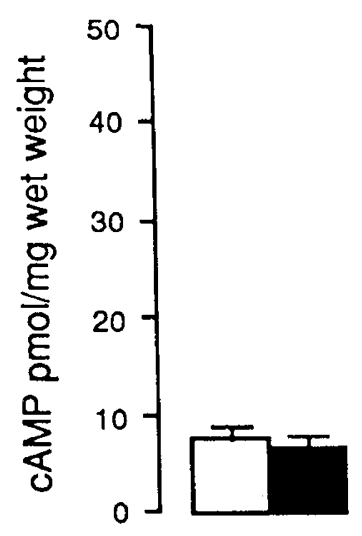

A Content

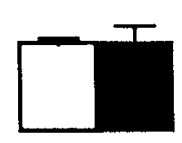

Basal
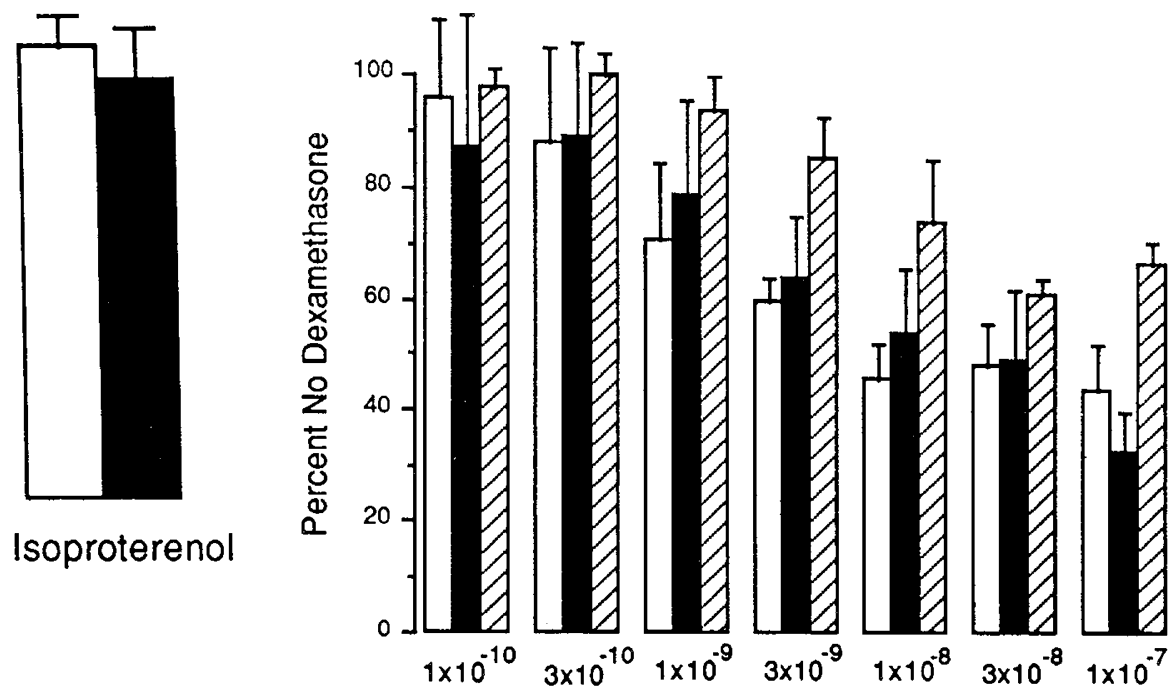

$\log$ Dexamethasone, $M$
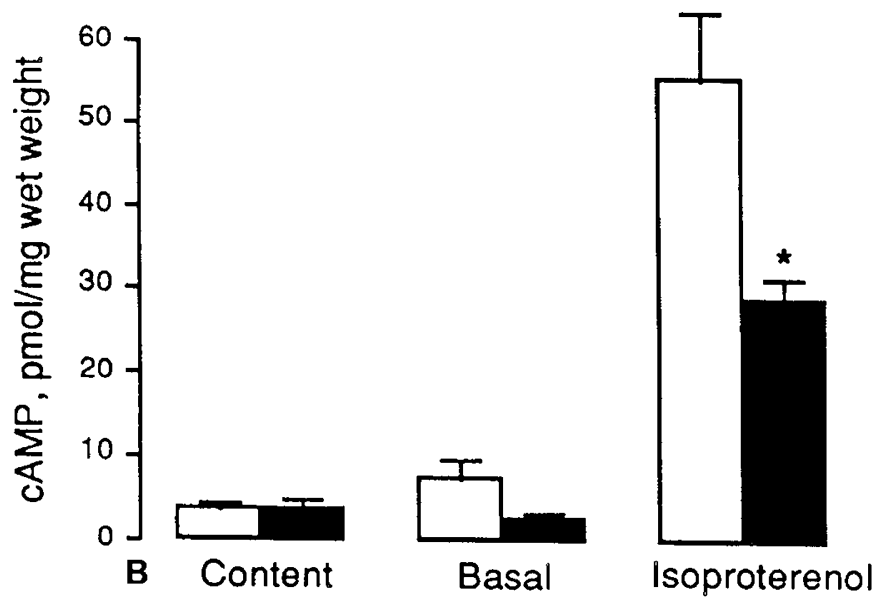

Fig. 4. cAMP generation for control and dexamethasone-treated (Dex) explants. $A, \mathrm{~d}$ 3. B, d 5. Data are the mean and SEM for duplicate determinations of seven sets of explants for both groups on d 3, eight controls on $\mathrm{d} 5$, and five dexamethasone-treated on $\mathrm{d} 5 .{ }^{*}$ indicates less cAMP stimulation than in control (analysis of variance, $p<0.05$ ). Open bar, control; solid bar, Dex.

during explant culture. Similarly, the ability of isoproterenol to stimulate cAMP generation, a $\beta$-adrenergic response, also spontaneously increases. These findings fit well with the work of others on the morphologic and biochemical maturation of human fetal lung in explant culture (4). The maximal concentration of $\beta$-adrenergic receptors after culture $(185 \pm 15 \mathrm{fmol} / \mathrm{mg} \mathrm{mem}$ brane protein) was not dependent on gestational age, and was similar to the receptor concentration we previously reported in the lungs from a stillborn at $39 \mathrm{wk}$ gestation $(223 \mathrm{fmol} / \mathrm{mg}$ membrane protein) (3). Thus, the human fetal lung in explant culture reaches a concentration of $\beta$-adrenergic receptors that approaches that which is normally found at term. This concentration of $\beta$-adrenergic receptors is less than that in human adult lung (470 fmol/mg membrane protein) (22), reflecting the postnatal increase common to several species. The rapid rise in $\beta$ adrenergic receptor concentration in human fetal lung between $\mathrm{d} 0$ and 3 in explant culture may be due to release from tonic in utero inhibitory control; alternatively, the increase may be secondary to culture conditions or to generation of some stimulatory factor during explant culture.

The ability of isoproterenol to stimulate cAMP generation also increased during explant culture. Unlike the $\beta$-adrenergic receptor concentration, which did not further increase after $3 \mathrm{~d}$ in culture, isoproterenol-stimulated cAMP generation continued to increase through $\mathrm{d} 5$. Thus, it appears that with increasing time

Fig. 5. Dose response of dexamethasone for stimulation of cAMP generation. Data are the mean and SEM expressed as \% of no dexamethasone treatment for duplicate determinations of three sets of explants; basal stimulation (open bar), isoproterenol $(1 \mu \mathrm{M})$ stimulation (closed bar), and forskolin $(100 \mu \mathrm{M})$ stimulation (cross-hatched bar). For all responses, dexamethasone doses greater than $3 \mathrm{nM}$ resulted in a significant reduction $(p<0.05$, analysis of variance) from control.

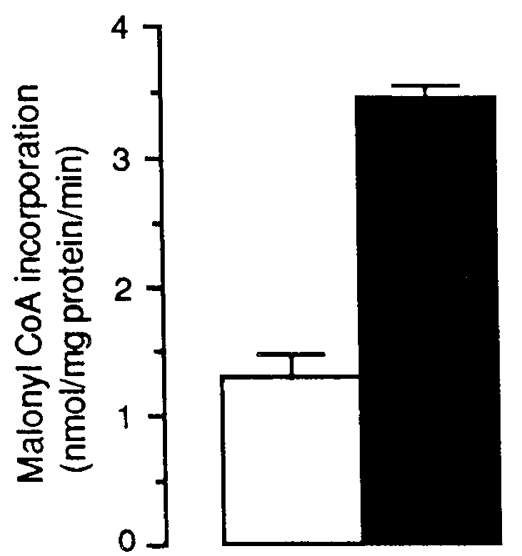

Fig. 6. Fatty acid synthetase activity in human fetal lung explants. Explants were cultured for 5 days with (open bar) or without (solid bar) $10 \mathrm{nM}$ dexamethasone. Shown are mean and SD of four sets of explants chosen from among those used for cAMP and $\beta$-receptor determinations. Assays were performed with triplicate determinations.

in culture, the occupancy of the $\beta$-adrenergic receptor is more "tightly coupled" to the other components of the $\beta$-adrenergic response cascade. This might be mediated through quantitative or qualitative changes in the stimulatory guanine-nucleotide regulatory protein $\left(\mathrm{G}_{\mathrm{s} \alpha}\right)$ or by changes in the catalytic component of adenylate cyclase. One can postulate that increased sensitivity of $\beta$-adrenergic receptors to agonists might also occur in vivo with advancing gestational age. We have found in studies using fetal rabbit lung that the interaction of agonist-occupied $\beta$ receptors with $G_{s \alpha}$ increases with advancing gestation before the increase in $\beta$-adrenergic receptor concentration (23).

An unexpected finding was that the concentration of $\beta$-adrenergic receptors in explants exposed to dexamethasone was less than in control explants harvested on the same day. Dexamethasone has been shown to increase morphologic maturation and phospholipid synthesis in human fetal lung in explant culture (13). We had anticipated that dexamethasone would also increase $\beta$-adrenergic receptor concentration and $\beta$-adrenergic responses 
in human fetal lung in explant culture, similar to its effect in different animal models (5-10). Despite the lower $\beta$-adrenergic receptor concentration in the dexamethasone-treated explants, isoproterenol-stimulated cAMP generation on d 3 in these explants was the same as in controls. However, by $\mathrm{d} 5$, isoproterenol-stimulated cAMP generation was less in the dexamethasonetreated explants.

These data demonstrate a time-dependent effect of dexamethasone on inhibiting the $\beta$-adrenergic response system of the human fetal lung. It is apparent that dexamethasone must exert its effect on sites in the $\beta$-adrenergic response system other than the $\beta$-receptor, inasmuch as both receptor-stimulated and basal cAMP generation are decreased. Further evidence for multiple effects is reduced cAMP stimulation by forskolin, an agent that acts beyond the receptor, in explants incubated with dexamethasone. Because at least part of the effect of forskolin is mediated by G-proteins, dexamethasone may decrease the activity of either G-proteins or the catalytic subunit.

There may be several reasons for the differences between the effects of glucocorticoids in animal studies and our results in human fetal lung in explant culture. One explanation for the results is that our culture conditions or an experimental artifact resulted in an unexpected, generalized inhibitory effect of dexamethasone on lung maturation in these experiments. To test this possibility, we examined fatty acid synthetase activity in four of the same explant sets (control and treated). As has been previously reported (13), there was a 2- to 3-fold increase in activity after exposure to dexamethasone, demonstrating that these particular explants could be stimulated by dexamethasone as expected. The human fetal lung explant culture is an appropriate model to study glucocorticoid effects; other studies have found morphologic maturation and increases in phosphatidylcholine and surfactant apoprotein synthesis $(13,24,25,26)$. The difference between our studies and those in animals may simply reflect a difference between species in the effect of glucocorticoids on the $\beta$-adrenergic response cascade. The $\beta_{1}$-receptor subtype, which predominates in rabbit fetal lung (1), may respond differently to dexamethasone treatment than the $\beta_{2}$-receptor subtype, which predominates in human fetal lung $(2,3)$. This could not explain the difference between rat and human fetal lung, both of which contain $\beta_{2}$-receptors. Another possibility is that the spontaneous increase in the concentration of $\beta$-adrenergic receptors in human fetal lung in explant culture is so great $(>250 \%)$ that further stimulation cannot occur. A spontaneous increase in receptor concentration of this degree was not observed in animal experiments (7). Timing of the experiments may also have played a role in these results. In mixed cell cultures of fetal rat lung, Smith and Sabry (27) have shown a marked rise in intracellular cAMP level that peaks at $6 \mathrm{~h}$ after exposure to cortisol. The earliest time at which we assayed cAMP generation in our specimens was approximately $16 \mathrm{~h}$ after exposure, so it is conceivable that we missed an early, transient peak effect of dexamethasone on CAMP generation. It is also possible that glucocorticoids have dual stimulatory and inhibitory effects. For example, dexamethasone stimulates staphylococcal protein A production at low doses and inhibits it at higher doses (24-26). However, dose-response experiments showed that there was no dose of dexamethasone that increased isoproterenol, forskolin, or basal cAMP generation and, furthermore, that there was a dose-related decrease in stimulation with increasing doses of dexamethasone. The median effective concentration of dexamethasone to reduce cAMP generation was $1 \mathrm{nM}$, similar to other glucocorticoid-mediated responses (choline incorporation into phosphatidylcholine and content of surfactant protein mRNA), which is consistent with mediation by glucocorticoid receptors.

Glucocorticoids and cAMP coinduce a number of lung proteins (surfactant proteins and fatty acid synthase), and these two mediators have the additive effects on the synthesis of surfactant lipids (18). It has been suggested that these glucocorticoid effects may be mediated through increased levels of cAMP $(24,27)$. Our finding that dexamethasone decreases cAMP generation does not support this proposal.

In summary, we have shown that there is a spontaneous increase in $\beta$-adrenergic receptors and in the response of these receptors to isoproterenol, as measured by the generation of cAMP, in human fetal lung grown in explant culture. Dexamethasone, a hormone that has been shown to accelerate other aspects of fetal lung maturation, inhibits this spontaneous increase. The sites of action of this effect are the $\beta$-receptor and distal adenylate cyclase components. It is possible that other hormones that accelerate lung maturation, such as thyroxine or prolactin, might be necessary cofactors to allow dexamethasone to enhance adrenergic responses in vitro.

\section{REFERENCES}

1. Roberts JM, Musci J 1986 Alveolar beta-adrenoreceptors: modulation and role in perinatal adaptation. In: Johnston BM, Gluckman PD (eds) Respiratory Control and Lung Development in the Fetus and Newborn. Perinatology Press, Ithaca, NY, pp 135-160

2. Falkay $G$, Nemeth $G$, Kovacs $L 1986$ Binding properties of beta-adrenergic receptors in early human fetal lung. Biochem Biophys Res Commun $135: 816-822$

3. Davis DJ, Dattel BJ, Ballard PL, Roberts JM 1987 Beta-adrenergic receptors and cyclic adenosine monophosphate generation in human fetal lung. Pediatr Res 21:142-147

4. Ballard PL 1986 Hormones and lung maturation. In: Gross F, Samuels LT (eds) Monographs on Endocrinology. Springer-Verlag, Berlin, pp 1-354

5. Cheng JB, Goldfien A, Ballard PL, Roberts JM 1980 Glucocorticoids increase pulmonary beta-adrenergic receptors in fetal rabbit. Endocrinology 107:1646-1648

6. Barnes P, Jacobs MM, Roberts JM 1984 Glucocorticoids preferentially increase fetal alveolar beta-adrenoreceptors: autoradiographic evidence. Pediatr Res 18:1191-1194

7. Roberts JM, Jacobs MM, Cheng JB, Barnes PJ, O'Brien AT, Ballard PL 1985 Fetal pulmonary beta-adrenergic receptors: characterization in human and in vitro modulation by glucocorticoids in rabbit. Pediatr Pulmonol 1 (suppl 3):S69-\$76

8. Giannopoulos G, Sommers Smith SK 1982 Hormonal regulation of betaadrenergic receptors in fetal rabbit lung in organ culture. Life Sci 31:795802

9. Maniscalco WM, Shapiro DL 1983 Effects of dexamethsone on beta-adrenergic receptors in fetal lung explants. Pediatr Res 17:274-277

10. Mano K, Akbarzadeh A, Townley RG 1979 Effect of hydrocortisone on betaadrenergic receptors in lung membranes. Life Sci 25:1925-1930

11. Fraser CM, Venter JC 1980 The synthesis of beta-adrenergic receptors in cultured human lung cells: induction by glucocorticoids. Biochem Biophys Res Commun 94:390-397

12. Davies AO, Lefkowitz RJ 1984 Regulation of beta-adrenergic receptors by steroid hormones. Annu Rev Physiol 46:119-130

13. Gonzales LW, Ballard PL, Ertsey R, Williams MC 1986 Glucocorticoids and thyroid hormones stimulate biochemical and morphological differentiation of human fetal lung in organ culture. J Clin Endocrinol Metab 62:678-691

14. Bradford MM 1976 A rapid and sensitive method for the quantitation of microgram quantities of protein utilizing the principle of protein-dye binding. Anal Biochem 72:248-254

15. Gilman AG 1970 A protein binding assay for adenosine $3^{\prime}: 5^{\prime}$ cyclic monophosphate. Proc Natl Acad Sci USA 67:305-315

16. Brooker G, Harper JF, Terasaki WL, Moylan RD 1979 Radioimmunoassay of cyclic AMP and cyclic GMP. In: Brooker G, Greengard P, Robison GA (eds) Advances in Cyclic Nucleotide Research. Raven Press, New York, pp 1-33

17. Gonzales LW, Ertsey R, Ballard PL, Froh D, Goerké J, Gonzales J 1990 Glucocorticoid stimulation of fatty acid synthesis in human fetal lung. Biochim Biophys Acta 1042:1-12

18. Roncari DAK 1981 Fatty acid synthase from human liver. Methods Enzymol 71:73-79

19. Roberts JM 1986 Techniques for the direct examination of adrenergic receptors in developmental studies: In: Nathanielsz PW (ed) Animal Models in Fetal Medicine. Perinatology Press, Ithaca, NY, pp 187-268

20. Scatchard G 1949 The attraction of protein for small molecules and ions. Ann NY Acad Sci 51:660-672

21. Gross I, Ballard PL, Ballard RA, Jones CT, Wilson CM 1983 Corticosteroid stimulation of phosphatidylcholine synthesis in cultured fetal rabbit lung: 
evidence for de novo protein synthesis mediated by glucocorticoid receptors. Endocrinology 112:829-837

22. Barnes PJ, Karliner JS, Dollery CT 1980 Human lung adrenoreceptors studied by radioligand binding. Clin Sci 58:457-461

23. Maier JA, Roberts JM, Jacobs MM 1989 Ontogeny of fetal adenylate cyclase: mechanisms for regulation of beta adrenergic receptors. J Dev Physiol 12:1025-1034

24. Ballard PL, Hawgood S, Liley H, Wellenstein G, Gonzales LW, Benson B, Cordell B, White RT 1986 Regulation of pulmonary surfactant apoprotein SP 28-36 gene in fetal human lung. Proc Natl Acad Sci USA 83:9527-9531
25. Whitsett JA, Pilot T, Clark JC, Weaver TC 1987 Induction of surfactant protein in fetal lung. J Biol Chem 262:5256-5261

26. Odom MJ, Snyder JM, Boggaram V, Mendelson CR 1988 Glucocorticoid regulation of the major surfactant associated protein (SP-A) and its messenger ribonucleic acid and of morphological development of human fetal lung in vitro. Endocrinology 123:1712-1720

27. Smith BT, Sabry K 1983 Glucocorticoid-thyroid synergism in lung maturation: a mechanism involving epithelial-mesenchymal interaction. Proc Natl Acad Sci USA 80:1951-1954

\section{Announcement}

\section{LABCATAL Prize to Promote Scientific Research in Field of Trace Elements}

A 1st prize of 35000 French francs and three 2nd prizes of 5000 French francs each will be awarded by the French company, Laboratoires LABCATAL, for scientific works on trace elements in the field of pharmacology or human therapeutics.

These prizes will be presented to winners at the scientific congress organized by the French Society for Essential Trace Element Study (SFERETE) in Les Deux-Alpes, France, January 14-18, 1991.

For further information on the LABCATAL prizes, please contact the Scientific Director, Laboratoires LABCATAL, 7 rue Roger Salengro, B.P. 305, 92541 Montrouge Cedex, France.

For further information concerning the congress organized by the SFERETE, please contact: Mrs. A. Alcaraz, Hopital A. Michallon, Laboratoire de Biochimie C, B.P. 217 X, 38043 Grenoble Cedex, France. 